\title{
JUDGMENT ENFORCEMENT IN WESTERN BALKANS
}

The paper wishes to analyse the similarities and the differences in judgment enforcement practices existing in the Western Balkans region (Albania, Bosnia and Herzegovina, Northern Macedonia, Montenegro, Serbia). In its first section, the paper presents alternatives in the enforcement formation stage, listing varieties in national enforcement title catalogues, as well as scrutinizing the legal nature and legal effects embodied by a writ of enforcement, or its absence. The second section deals with the enforcement implementation stage, presenting applicable enforcement assets (personal, real, or intellectual property, receivables, negotiable instruments, various ownership interests, freezing order). In addition, the paper analyses the statutory absence of the gradus executionis principle, though its reflections can still be traced in manners enforcement is implemented in the region. In its last section, the paper deals with different national enforcement agent structures. Having in mind that almost all Western Balkans jurisdictions (except Bosnia and Herzegovina) have recently introduced the French (even Napoleonic) concept of a self-employed judicial officer (huissier de justice), the paper also presents their prerogatives and connections with state administration.

Keywords: judgment enforcement, Western Balkans, writ of enforcement, means of enforcement, enforcement agent

\section{INTRODUCTION}

More than two decades ago, the European Court of Human Rights (ECoHR) defined 'fair and efficient enforcement' as an integral part of the human rights catalogue as specified by the famous 1950 Convention. In its flagship Hornsby $y^{316} \mathrm{case}$, ECoHR found that a right to a fair trial, as stipulated in Art. 6 of the European Convention, would be "illusory if a Contracting State's domestic legal system allowed a final, binding judicial decision to remain inoperative to the detriment of one party. [...] Execution of a judgment given by any court must therefore be regarded as an integral part of the 'trial' for the purposes of Article 6". 317

\footnotetext{
* Secretary General of the Balkan Enforcement Initiative (www.balkaninitiative.net), ORCID No. 0000-00028273-9188. Email: email@damir.site.

${ }^{316}$ Hornsby $v$ Greece, 1997.

${ }^{317}$ Hornsby $v$ Greece, 1997, point 40.
} 
A dilemma whether a country has violated Art. 6 of the Convention only when failing to provide fair and efficient enforcement based on a court judgment, having in mind that in many jurisdictions a number of enforcement titles are not judicial in nature (e.g. bills of exchange, notarial instruments), was resolved not longer than just a year later. In the 1998 Estima Jorge $v$ Portugal case, ECoHR adjudicated that an enforcement proceeding initiated by a notarial deed of mortgage, regardless of the fact that it is not judicial in nature, falls within the right to a fair trial requirement. The Court has specifically declared that irrespective of whether the authority to enforce takes the form of a judgment or a notarial deed, "[c] onformity with the spirit of the Convention requires that the word 'contestation' (dispute) should not be construed too technically and that it should be given a substantive rather than a formal meaning". 318

This approach led to the creation of a number of legal instruments dealing with enforcement within the European legal orbit, administered by its two most prominent entities: the Council of Europe and the European Union. The former went even as far as establishing its specialized body, Commission for the efficiency of justice (CEPEJ), whose objective is related to monitoring the efficiency enforcement procedures generatein the Council of Europe member states.

The ongoing pan-European integration processes, advanced notably by the fall of the Berlin Wall, had a further influence on cross-border enforcement on the Old Continent. It was clear that the "Four Freedoms" blueprint, one of vital EU aspirations, would be extremely difficult to achieve without creating clear legal mechanisms for cross-border enforcement within the internal market. For this reason, acquis communautaire at its early stages established the so-called Brussels Regime, i.e. a number of legal instruments aimed at enhancing cross-border justice within the EU. ${ }^{319}$

The Western Balkans region, being focused on becoming an integral part of the European Union, has been trying for a number of years to establish a legal framework that would secure fair and efficient enforcement, as defined by the Council of Europe regulations. (Albania became a CoE member in 1995, Bosnia and Herzegovina in 2002, Northern Macedonia in 1995, Montenegro in 2007 and Serbia in 2006 - the last two countries had previously been a CoE member as the State Union of Serbia and Montenegro since 3 April 2003).

Since the prevailing part of the region (except Albania) shares a common Yugoslav legal heritage (Bosnia and Herzegovina, Northern Macedonia, Montenegro and Serbia), challenges associated with the enforcement system reform were relatively common. A universal Yugoslav judgment enforcement regulation was put in practice at the beginning of 1938, based on its first consolidated Enforcement and Security Interests Act (Zakon o izvršenju i obezbeđenju). This Act introduced the Austrian model of court-focused enforcement on the territory of the whole state, replacing previous provincial differences. ${ }^{320}$

\footnotetext{
${ }^{318}$ Estima Jorge v Portugal 1998, point 37.

${ }^{319}$ Brussels Regime: Brussels Convention (1968), Lugano Convention (1988), Brussels I Regulation (2001), Lugano convention (2007), Brussels I Regulation - recast (2012).

320 The former Austrian parts of Yugoslavia (Slovenia, Dalmatia) together with Croatia (a separate kingdom within the Kingdom of Hungary) and Bosnia and Herzegovina (a condominium under joint control of Austria and Hungary) had an approximately similar court-focused enforcement, with some prerogatives of notaries in
} 
The later (post-World War II) 1974 Yugoslav federal Enforcement Procedure Act upheld the practice of court-focused enforcement procedure. Following the dissolution of the country in the 1990s, newly independent former Yugoslav states initially continued with the predominantly court-focused enforcement resulting in a significant backlog of enforcement files. Correspondingly, substantial reforms of enforcement systems were carried out in almost all post-Yugoslav jurisdictions.

Albania belongs to the group of European jurisdictions that has not enacted separate enforcement legislation. Its enforcement regulations are an integral part of the Albanian Code of Civil Procedure (Sections IV and VI). ${ }^{321}$ Enforcement implementation, similar to the earlier Soviet method, is carried out by state officers belonging to a separate enforcement structure, under the supervision of the Ministry of Justice.

At present, in almost all Western Balkans jurisdictions (except Bosnia and Herzegovina), enforcement can or must be carried out by self-employed judicial officers. With respect to the structure of Bosnia and Herzegovina, enforcement legislation in this country is enacted on sub-national levels (with separate enforcement statutes of the Republic of Srpska, the Federation of $\mathrm{B} \& \mathrm{H}$, and the District of Brčko).

\section{ENFORCEMENT FORMATION}

\subsection{Enforcement title}

Enforcement procedure is initiated subject to a valid enforcement title being held by the claimant. An enforcement title can be judicial or non-judicial in origin.

Each jurisdiction based on former Yugoslav legislation shares a common subdivision of enforcement titles into two principal categories: 'enforceable instruments' (izvršna isprava) and 'authentic instruments' (verodostojna isprava). The difference between these two categories rests on dissimilarities of legal effects a possible appeal filed by a defendant (a so-called enforcement debtor) can create. Should a defendant object an enforcement procedure deriving on an authentic instrument, in many cases the court will initiate a separate litigation in order to judicially resolve the debtor-creditor relations between the parties, resulting a stay of enforcement.

A list of enforceable instruments (izvršna isprava) in a majority of post-Yugoslav jurisdictions can be defined to an extent as judicial in nature; namely an enforceable instrument cannot originate from the parties, but only from competent institutions (courts and related public officials, e.g. notaries, judicial officers, state and local government authorities). Enforceable instruments are judgments, court orders and court settlements, pecuniary orders issued by state public officials, notarial enforcement titles, etc.

Croatia.Enforcement in former Hungarian parts (Vojvodina, Međimurje County) was conducted by self-employed private enforcement officers established in 1871 (modelled after the Napoleonic huissiers de justice).In former Kingdom of Serbia and Kingdom of Montenegro enforcement procedure was implemented exclusively by the police.

${ }^{321}$ European jurisdictions that have maintained enforcement as chapters in their civil procedure codes include Lithuania, Luxembourg, Belgium, Greece, Bulgaria, etc. 
The only exception in the region, in regard to the nature of enforceable instruments, is found in Serbia. Distinctively, since 2011 its legislation has defined a number of clearly private documents as enforceable instruments (in specie: a mortgage contract, a mortgage deed, and a certified copy of an entry from a National chattel charge register). A common criterion regarding the listed private documents is that all of them belong to the group of voluntary liens.

Authentic instruments (verodostojna isprava) are a selection of private documents (they originate from the parties themselves) bearing a certain level of validity with respect to the existence of an enforceable monetary claim. Authentic instruments were introduced into the Yugoslav enforcement legislation in 1974, initially as a possibility limited only to commercial transactions between businesses. The original list of authentic instruments was limited to not more than three: invoice, bill of exchange ${ }^{322}$, and cheque. ${ }^{323}$

Subsequent changes in Yugoslav and national legislations of succeeding independent jurisdictions (Bosnia and Herzegovina, Northern Macedonia, Montenegro, Serbia), extended the scope of implementation possibilities authentic instruments subsume in enforcement. First of all, their applicability was expanded to all debtor-creditor relations, irrespective of whether they are commercial (B2B) or personal in nature (B2C), including even those between individuals. Also, the initial list of three statutory authentic instruments has been broadened. Bosnian and Northern Macedonian jurisdictions have not added much to the basic list, extending it only with bookkeeping records of utility companies for services provided to the general public (like water, sewage, electricity, heating, telephone and internet, public parking). The Republic of Srpska legislation has also included their National Bar Association's book debts on lawyers' membership fees.

Northern Macedonian legislation sets forth two types of authentic instruments: those which can eventually effectuate enforcement (invoice, bill of exchange, cheque, bookkeeping records of financial institutions - banks, credit unions, insurance and hire purchase corporations), and those leading to amicable debt collection (utility accounts up to a certain claim value - approximately $€ 30$ for water, sewage, telephone, cable TV, and $€ 100$ for heating and electricity).

Serbian and Montenegrin legislations have widened the initial list of authentic instruments to a much greater extent than other jurisdictions in the region. Apart from accounting tools that define utility based pecuniary liabilities used in all post-Yugoslav jurisdictions, Serbian and Montenegrin statutory lists of authentic instruments bearing legal capacity to initiate enforcement include bonds, letters of credit, bank guarantees, certified written statements issued by defendants authorising their banks to transfer funds to nominated claimants, interest rate calculations supported with evidence on principal and its maturity, certified construction specifications on final or on-going work completion, etc. Serbian legislation has enlarged this comprehensive list with three additional documents: those defining duties with respect to the National Broadcasting Corporation, attorneys' fee calculations and any public document setting forth a pecuniary

322 In this paper the term 'bill of exchange' also includes a promissory note.

323 Article 21 of the 1974 Yugoslav Enforcement Procedure Act. 
obligation. Montenegrin legislation adds only one specific authentic instrument: statement of accounts executed (signed) by both parties (claimant and defendant).

Albanian legislation does not contain stratifications similar to that of post-Yugoslav jurisdictions in respect of its enforcement titles (enforceable vs. authentic instruments). Article 510 of the Albanian Civil Procedure Code (Kodi i Procedurës Civile) in seven points (a-e) sets forth its variety of enforcement titles (titujtekzekutivë). These include final decisions of civil courts containing an obligation, defining a security interest or allowing temporary enforcement, irrevocable decisions of criminal courts dealing with property rights, decisions of domestic and foreign arbitral tribunals (subject to accordance with relevant Albanian legislation on the latter), notary instruments containing monetary obligations, documents related to bank loans, bills of exchange, cheques, and similar financial instruments.

All Western Balkans legislations resort to an open ending provision stipulating that a directory of enforcement titles can be extended by any instrument defined as such by other statutes. For example, Northern Macedonian list of authentic instruments bearing legal capacity to initiate enforcement is defined in their Notaries Act. In Serbia, an additional enforceable instrument is set forth in the Employment Act (employer payroll calculation).

\subsection{Writ of enforcement}

Enforcement procedure in Western Balkans jurisdictions can be subdivided into two major consecutive stages: 1) enforcement formation and 2) enforcement implementation.

Enforcement formation is the initial phase of enforcement whose primary component is the issuance of a separate document - the writ of enforcement. ${ }^{324} \mathrm{~A}$ writ of enforcement is (usually) rendered by a court, subject to examination whether the claimant requesting enforcement holds a valid enforcement title. Enforcement procedure is characterised by a somewhat particular principle of formal legality, whose major distinction is that a writ of enforcement is bound (or limited) to claims and parties already set forth in the enforcement title.

Consequently, a defendant aspiring to challenge a writ of enforcement, due to the abovementioned principle, can usually resort only to two major objections: the invalidity of the enforcement title, or the fact that the claim is premature or it has already been cleared (paid). Formerly, the second stage of enforcement (implementation) could begin only after the writ of enforcement becomes final, that is only after a possible appeal filed by the defendant has been examined by the competent court. Nowadays, Western Balkans legal systems tend to give more weight to the enforcement title itself, meaning that in a number of cases, an appeal filed by a defendant would not result in stay of enforcement. This approach led to a significant procedural advancement, that is the shift from enforcement formation to enforcement implementation became much more straightforward.

${ }^{324}$ In this paper, the phrase writ of enforcement is used in order to denote a specific court decision found in a number of civil jurisdictions used in order to initiate an enforcement procedure (Albanian: urdhriiekzekutimit, Serbian: rešenje o izvršenju). 
Post-Yugoslav jurisdictions implement a specific distinction in writs of enforcement depending whether it is rendered based on an enforceable instrument (izvršna isprava), or an authentic instrument (verodostojna isprava). In the former case, a writ of enforcement shall only contain a court order permitting the requested enforcement. In the latter, a writ of enforcement would first mandate the defendant to satisfy the claim in a statutory period of 8 days, and should a defendant fail to comply, enforcement is instituted automatically.

The most far-out regulatory change in the region in this respect has been introduced by the Northern Macedonian legislation. Enforcement initiation in that jurisdiction is not defined by a writ of enforcement (which has been omitted), but by a motion filed by a claimant supported with a valid enforceable instrument (izvršna isprava), resulting in an automatic outset of the enforcement implementation stage. ${ }^{325}$ Should a claimant hold an authentic instrument (verodostojna isprava), it is filed with a notary who issues a payment order which, if uncontested, becomes an enforceable instrument.

Montenegrin legislation, though, has not gone so far as to abolish a separate writ of enforcement, yet nevertheless bears certain distinctiveness in respect of other Western Balkans jurisdictions. Namely, in predominant number of cases a writ of enforcement is not rendered by a court, but by a self-employed judicial officer (javni izvršitelj).

In the remaining Western Balkans jurisdictions, a writ of enforcement is issued only by courts, with the exception of Serbia, where self-employed judicial officers (javni izvršitelj) render writs of enforcement in utility related claims, and in claims against the State or its subordinate agent. In Albanian and Bosnian jurisdictions, a writ of enforcement can be rendered only by a competent court.

In Albania, a writ of enforcement is issued in only one copy (a duplicate may be made based on a special request filed by the creditor), which the claimant files with the enforcement agent. Also, a writ of enforcement shall not be rendered in respect of court fines and court fees, or court orders for taking of evidence. In these situations, enforcement is initiated when a notice of such court decision has been served to the defendant by an enforcement agent.

\subsection{Available remedies and their legal effect}

In a majority of post-Yugoslav jurisdictions, a defendant may challenge a writ of enforcement filing an objection (prigovor). An appeal (žalba) can be used only in a limited number of situations.

In Montenegro, an objection will be examined by a panel of three first-instance court judges. In general, should an objection be filed against a writ of enforcement based on an enforceable instrument (izvršna isprava) it does not result in stay of enforcement. If the objection is deposited against a writ of enforcement based on an authentic instrument (verodostojna isprava), it results in stay of enforcement (except for bills of exchange).

In Bosnian jurisdictions (the Federation of $\mathrm{B} \& \mathrm{H}$, the Brčko District and the Republic of Srpska) a writ of enforcement is challenged by an objection which can be examined

${ }^{325}$ Similar practices can be found in other European jurisdictions as well (e.g. France). 
by a first-instance court and in some cases by a court of appeal. If filed, an objection in general does not result in stay of enforcement.

In Serbia, a defendant may protest against a writ of enforcement by means of appeal (žalba) and objection (prigovor). An appeal is filed opposed to a writ of enforcement based on an enforceable instrument (izvršna isprava), and is examined by a second-instance court. If filed, an appeal does not induce stay of enforcement. An objection filed against writs of enforcement rendered upon authentic instruments (verodostojna isprava) result in automatic stay of enforcement (save in situations when the writ of enforcement is based on a bill of exchange). It is examined by a panel of three first-instance court judges. If not satisfied with the first-instance ruling, a defendant may oppose this decision with an appeal falling within the competence of a second-instance court.

In Northern Macedonia a defendant may oppose enforcement by means of an objection (prigovor) arguing that enforcement is unlawful, or that a judicial officer has committed irregularities in his actions. This atypical scope of available remedies (different from prevailing appeal-like motions) rests on the fact that Northern Macedonian legislation has omitted writs of enforcement, and a defendant may only challenge enforcement after its implementation has already commenced. The ruling of the first-instance court may be disputed by an appeal (žalba) examined by a court of appeal.

In Albania, a defendant has a statutory period of 30 days upon receiving the enforcement notice to file a separate request asserting that the enforcement title is invalid, that the duty ceased to exist or that it has been reduced (pavlefshmëria e titullitekzekutiv). In these cases, the court may decide to put the enforcement title aside and suspend its implementation with or without a monetary guarantee.

In situations when the enforcement title is a security interest created on behalf of a bank or another financial institution used to obtain a loan, the court may decide to order a stay of enforcement, but in these situations amonetary guarantee is mandatory, and the suspension period cannot extend 3 months.

The court examines the suspension motion within 5 days, and its decision is subject to an appeal. A court of appeal shall examine such motion within 30 days from the date of its filing in this court. A second-stage decision can also be challenged by a special appeal which has to be adjudicated upon within a statutory sixty-days period.

\section{ENFORCEMENT IMPLEMENTATION}

Second consecutive stage of the enforcement procedure is enforcement implementation. Commonly, this phase used to be introduced after the writ of enforcement had become final, that is when all regular appeal instances were or could be exploited. Nowadays, the majority of remedies available to defendants in enforcement do not eventuate in stay of enforcement, meaning that enforcement measures can be imposed almost simultaneously with the issuance of a writ of enforcement.

Enforcement implementation, put simply, is a group of compelling measures inflicted on a defendant (enforcement debtor), or more precisely: defendant's assets, activated in order to satisfy the claim defined in the enforcement title, considering the debtor's 
unwillingness to comply voluntarily. In all of Western Balkans jurisdictions enforcement measures are somewhat complementary. They include auctioning defendant's moveable, immovable or intellectual property, ordering attachments on a defendant's income (wage, salary or pension garnishment) or other assets owed to the defendant by third parties, freezing bank accounts, or sale of defendant's securities (tradable financial assets like shares, bonds, debentures, etc.).

In all post-Yugoslav jurisdictions enforcement implementation is induced simultaneously with the issuance of the writ of enforcement whenever it is rendered based on an enforceable instrument (izvršna isprava). Any of the enforcement measures defined by the writ of enforcement can automatically be put into motion, and the defendant is compelled to respect them. In other words, an enforcement agent is in a position to automatically perform all the necessary enforcement steps, like seizure of defendant's movable, immovable or intellectual property, enact garnishment and attachment orders, freeze the defendant's bank accounts, etc.

In Bosnian jurisdictions (the Federation of $\mathrm{B} \& \mathrm{H}$, the Brčko District and the Republic of Srpska), if performed enforcement measures result in money collection, accrued funds are not to be transferred to the claimant before the writ of enforcement becomes final.

When the writ of enforcement is based on an authentic instrument (verodostojna isprava) enforcement implementation is not possible before it becomes final. The only exception in this respect is enforcement based on bills of exchange when an objection or an appeal does not induce stay of enforcement.

In Northern Macedonia, having in mind that this jurisdiction has omitted the writ of enforcement, enforcement implementation is commenced when the claimant has filed his request for enforcement with the competent judicial officer (izvršitel).

In Albania, the enforcement implementation stage is initiated after the claimant has filed a specific request with the enforcement agent (state or self-employed) seeking enforcement implementation. To this motion, a claimant has to attach the corresponding enforcement title and the writ of enforcement. An enforcement agent has a statutory duty to commence the procedure within 15 days from the date when the request was filed. Similar legislative framework exited in Serbia from 2011 to 2016, in the initial period of the then newly introduced self-employed judicial officers. A claimant holding the writ of enforcement had to file a separate request for enforcement implementation to the judicial officer of his choice. The 2015 changes of the Serbian enforcement legislation abolished this two-fold enforcement structure.

Upon receiving a separate request from the creditor, an enforcement agent in Albania invites the debtor to satisfy the claim defined in the writ of enforcement within 5 or 10 days. If a defendant suggests payment in instalments, subject to claimant's unequivocal consent, an enforcement agent may allow such payments. If such motion was not filed by the defendant, or it was not agreed on by the claimant, after the statutory period of 5 or 10 days, enforcement implementation is initiated.

In all Western Balkans jurisdictions enforcement measures necessary for satisfying the claim can be implemented chronologically (one by one) or simultaneously more of them at once (e.g. auction of the defendant's moveable property combined with salary 
garnishment). The officer in charge (judge or an enforcement agent) is required to resort to enforcement measures being most advantageous for both parties, that is, that will result in fair and efficient enforcement.

Western Balkans jurisdictions in their enforcement implementation do not use the Germanic gradus executionis principle in which enforcement measures are to be introduced in a pre-defined sequence (e.g. initially auctioning movables, if unsuccessful, putting attachment on receivables, and finally if both unsuccessful run public sale of immovable property). This concept can be traced to the very roots of European legal history, as far as Roman law. For example, one of eminent historical English legal documents, Magna Carta, in its point 9 sets forth the sovereign's promise that "Neither we nor our officials will seize any land or rent in payment of a debt, so long as the debtor has movable goods sufficient to discharge the debt." Such mandatory progression in imposed enforcement measures has been set aside in a majority of European jurisdictions.

\section{ENFORCEMENT OFFICIALS}

Enforcement procedure in the Western Balkans is judicial in nature. The central role in enforcement is committed to civil courts. This role is predominantly visible in the enforcement formation stage, having in mind that, with the exception of Montenegro, Northern Macedonia, and to a certain extent Serbia, all of the Western Balkans jurisdictions legislate that a writ of enforcement has to be rendered by a competent court. Northern Macedonian singularity rests on the fact that their regulators have decided to omit writs of enforcement, while the Montenegrin inconsistency is found on writ of enforcement rendering prerogatives being transferred to their judicial officers (javni izvršitelj).

In Northern Macedonia, a special role is given to notaries whose statutory authority is to issue payment orders based on authentic instruments which, if uncontested, become enforceable instruments. Serbian judicial officers (javni izvršitelj) are empowered to issue writs of enforcement for utility debts and claims against the State.

Nevertheless, the enlisted dispensation of similar legal capacities between courts, notaries and judicial officers in respect of writs of enforcement do not in any way reduce the central role that a court has in enforcement. Bearing in mind that due to the already mentioned formal legality principle writs of enforcement are based on previously set debtor-creditor relations (as defined in enforcement titles), prerogatives transferred to other officials are not without clear legal justification. If uncontested, a writ of enforcement is no more than a simple verification of a legal liaison already existing between the parties, meaning that there is no dispute to resolve.

On the other hand, if challenged, the final adjudication of objections, appeals and other available remedies is entrusted to the exclusive competence of courts. Likewise, in the enforcement implementation stage, any motion filed by the parties or other participants in enforcement related to alleged irregularities in enforcement procedure are finally decided by competent courts.

Actual enforcement actions, similar to the general European practice, are never carried out by judges or magistrates, but by particular court or self-employed officials. In 
all of the Western Balkans jurisdictions, with the exception of Bosnia and Herzegovina, enforcement procedures are solely or predominantly (Albania) performed by self-employed judicial officers, modelled after the Napoleonic concept of huissiers de justice. These legal professionals were introduced in the region in 2006 with their inauguration in Northern Macedonia. In subsequent years this judicial profession was instituted in Albania (2010), Serbia (2012) and Montenegro (2013). In all of these jurisdictions, with the exception of Albania, judicial officers are the only officials authorised to carry out enforcement measures.

In Bosnian jurisdictions, the enforcement implementation stage is still carried out exclusively by courts and their in-house personnel. This approach remains from the common former Yugoslav enforcement system, which was based on the Austrian Gerichtsvollziehe rconcept. However, recent changes in Bosnian enforcement legislations have introduced specific 'enforcement officers by contract' (commissioned or outsourced enforcement agents) with prerogatives only in utility-based claims, and which are in a position to implement enforcement measures purely on defendant's moveable property.

\section{CONCLUSION}

The significance of judgment enforcement in civil law corresponds with the gravity penal sanctions bear within the criminal justice system. A probability of successful neglect of judgments, injunctions, court orders, or other enforcement titles inevitably imposes critical consequences to a given society and its economy. Though an enforcement debtor is not a thief, the very prospect of achievable disrespect regarding mature civil obligations, taken from the angle of a non-breaching party, result in somewhat similar proprietary effects.

Efficient and fair enforcement has been recognized as a vital part of a right to a fair trial, as defined in Art. 6 of the European Convention on Human Rights. The Council of Europe and the European Union, both separately and in cooperation, have created a number of legal instruments and mechanisms aimed at effectuating enforcement that is adequate to satisfy valid expectations of creditors while safeguarding the protective rights of debtors.

Western Balkans jurisdictions have been active in adjusting their national regulative frameworks aiming to achieve European standards in enforcement. In this respect significant changes have already been made. Abolishment of inessential appeal and objection possibilities, limited opportunities of the stay of enforcement remedy, as well as the introduction of self-employed judicial officers are some of the most striking examples.

Improvements achieved on national levels should now be advanced to the arena of cross-border enforcement. The out-of-date exequatur requirement, a clear symbol of a Cold War Europe, has to take its honourable place in regional legal museums. International, or supranational possibilities that have been existing in European cross-border enforcement for many years now, enacted by the Brussels Regime, should became a new legal standard in the Western Balkans as well. Instruments like 'Balkan Enforcement Order', 'Balkan Payment Order', or similar legal mechanisms drafted after their senior European siblings, can be developed quite easily.

It seems that the initial stage of such regional cross-border enforcement cooperation should be used only in commercial transactions. After a period of careful scrutiny 
and implementation analysis, regional regulators would be in a position to advance implementation of such mechanisms by extending their applicability on other debtorcreditor relations.

Examples of current regional cross-border enforcement cooperation show that Europe has already gone beyond established legal channels. As an illustration, we can indicate Finland and Estonia, two neighbouring countries that have, for some time now, been exchanging public residence registers of their citizens on a weekly basis. This practice resulted in a clear possibility for authorised officials of these two jurisdictions to directly access official public information on defendants' place of residence and thus significantly reduce somewhat complicated cross-border service of documents procedure. In the modern post-Checkpoint Charlie world, such cooperation is not just feasible, but also extremely important. 


\section{List of references}

Books, articles

Fricero, N., Payan, G., 2014, Le droit à l'exécutionet le droit de la notification et de la signification dans la jurisprudence européenne. Paris: UIHJ Publishing.

Isnard, J., et al., 2002, Hostiarii, Paris :Éditions Juridiques et techiques.

Kruse, J., 2009, Law of Seizure of Goods, Ringwood :Hammicks Legal Publishing.

Latković, V., 2019.Javnoizvršiteljska služba - povodom pet godina rada javnih izvršitelja. Pravnizbornik. No. 3/2019.Pogdorica: Udruženje pravnika Crne Gore. pp. 333-348.

Latković, V., 2020.Izvršenje na nepokretnosti. Pravni zbornik No. 1/2020. Pogdorica: Udruženje pravnika Crne Gore. pp. 297-324.

Payan, G., 2017, Efficasité de l'exécution des décisions de justice dans la monde, Paris : UIHJ Publishing.

Podkonicky, J., 2014. Problematic issues of sale of seized assets of the debtor: the differences in the countries of the Balkan region. In: Parfenchikov, A., and Gureev, V., (eds.), Modern problems of foreclosure on the debtor's property and the ways of their solution. Moscow: Ural State University, pp. 328-331.

Račić, R., 2019. Sprovodivost stranih izvršnih naslova u Crnoj Gori. Pravni zbornik. No. 3/2019.Pogdorica:Udruženje pravnika Crne Gore. pp. 69-88.

Trešnjev, A., 2018. Od službenih lica do javnih izvršitelja. In: Šarkić, N., et al., (eds.), Četrdeset godina izvršnog zakonodavstva u građanskim postupcima, zbornik radova, Beograd: Pravni fakultet Univerziteta Union / Službeni glasnik, pp. 295-310.

Uitdehaag, J. \& Vincken, E. 2011.Civil Enforcement in the Western Balkans. Tirana: Balkans Enforcement Reform Project - BERP.

International regulative framework, case law

CEPEJ(2009)11E / 17 décembre 2009; European Commission for the Efficiency of Justice (CEPEJ) - Guidelines for a better implementation of the existing Council of Europe's Recommendation on enforcement;

Enforcement of Court Decisions in Europe, European Commission for the Efficiency of Justice / CEPEJ (2008), Report prepared by the Research Team on enforcement of court decisions (University Nancy (France) / Swiss Institute of comparative law) and discussed by the CEPEJ-GT-EVAL at their 8th meeting;

European Commission on the efficiency of justice (CEPEJ), Guidelines for a better implementation of the existing Council of Europe's Recommendation on enforcement CEPEJ (2009) 11 REV; 
Recommendation $\operatorname{Rec}(2003) 17$ of the Committee of Ministers to member states on enforcement, adopted by the Committee of Ministers on 9 September 2003 at the 851st meeting of the Ministers' Deputies.

Hornsby v Greece1997.ECtHR 19 March 1997, no. 18357/91.

Estima Jorge v Portugal 1998.ECtHR 21 April 1998, no. 24550/94.

Pini and Others v Romaina 2004. ECtHR 22 June 2004, no. 78030/01.

Western Balkans legislation

Kodii Procedurës Civilei Republikës Së Shqipërisë (Miratuar me ligjin No. 8116/1996, etc.).

Zakon o izvršenju i obezbeđenju (Službeni glasnik Republike Srbije br. 106/2015, etc.).

Zakon o javnim izvršiteljima (Službeni list Crne Gore br. 61/2011, etc.).

Zakon o izvršnom postupku (Službeni glasnik Republike Srpske br. 59/2003, etc.).

Zakon o izvršnom postupku Federacije BiH (Službene novine Federacije BiH br. 32/2003, etc.).

Zakon o izvršnom postupku Brčko distrikta Bosne i Hercegovine (Službeni glasnik Brčko distrikta BiH br. 39/2013, etc.).

Zakon za notarijatot (Služben vesnik na Republika Makedonija br.72/16, etc.).

Zakon za izvršuvanje (Služben vesnik na Republika Makedonija br. 72/16, etc.).

Zakon o izvršenju i obezbjeđenju (Službeni list Crne Gore br. 36/2011, etc.). 